\title{
Perancangan dan Implementasi Alat Rekam Data Stock Opname Berbasis Single Board Computer (SBC)
}

\author{
Badie Uddin ${ }^{1}$; Deny Mulyadi ${ }^{2}$; Ari Sudrajat ${ }^{3}$ \\ ${ }^{1}$ Department of Computer Science, Bogor Agricultural University, Indonesia \\ ${ }^{2}$ Department of Computer Engineering, TEDC Polytechnic, Indonesia \\ ${ }^{3}$ Department of Informatics Engineering, TEDC Polytechnic, Indonesia \\ badie.uddin@gmail.com \\ 2mulyadi.deny@gmail.com \\ 3arisud@poltektedc.ac.id
}

\begin{abstract}
Stock opname activity is an activity to count items between the system data and their real conditions. As a large retail company, BRM Group has a large number of goods at each of its outlets. In carrying out stock taking, there is often an error from the user when inputting and making reports on stock taking data, because at this time stock opname is still using the Input Stock Opname Form (FISO), not only for checking items but also for re-entering checking results into the system. A new system needs to be built that can carry out stock opname activities to match the inventory taking reports with their real conditions and it is not just displaying the stock taking reports from the system alone. The system built is capable of receiving data input and making reports based on their real condition inventory data digitally, namely utilizing a barcode scanner that functions to read the barcode, as well as stock opname record applications developed with PHP and MySQL as its database and based on a Single Board Computer. This stock opname data recording tool is portable, so it can store data throughout the BRM Group oulet. Test results show that this system is able to function properly as a prototype. As the tool reads the barcode, it can translate the barcode so that it can display the detail information and enter the amount of the item. Furthermore, when the application has saved the input data, it will display the stock opname report data, which is the final step in the process of stock opname.
\end{abstract}

Keywords: Stock Opname, BRM Group, Single Board Computer, Application, Portable

\begin{abstract}
ABSTRAK
Kegiatan stock opname yaitu menghitung barang antara data sistem dengan fisik di lapangan. Sebagai perusahaan ritel yang besar BRM Group memiliki jumlah barang yang banyak di setiap outlet-nya. Dalam melakukan kegiatan stock opname sering terjadi kesalahan dari user saat penginputan dan pembuatan laporan data stock opname, karena saat ini aktifitas stock opname masih menggunakan Form Input Stock Opname (FISO), baik untuk pengecekan barang maupun memasukkan kembali data hasil pengecekan ke dalam sistem. Perlu dibangun sistem baru yang dapat melakukan kegiatan stock opname untuk mencocokkan antara laporan stock opname dengan jumlah fisik barang, tidak hanya menampilkan laporan stock opname dari sistem saja. Sistem yang dibangun mampu menerima input data dan membuat laporan data stock opname fisik barang secara digitalisasi, yaitu memanfaatkan barcode scanner yang berfungsi membaca kode barcode barang, serta aplikasi rekam data stock opname yang dikembangkan dengan PHP dan MySQL sebagai database-nya serta berbasis Single Board Computer. Alat rekam data stock opname ini portable, sehingga dapat menyimpan data seluruh oulet BRM Group. Hasil pengujian menunjukan bahwa sistem ini mampu berfungsi dengan baik pada sebagai prototype. Pada saat alat rekam data stock opname ini membaca kode barcode maka aplikasi rekam data stock opname akan menerjemahkan kode barcode barang tersebut sehingga kode barcode barang dapat menampilkan informasi detail dan memasukan jumlah barang tersebut. Selanjutnya ketika aplikasi rekam data stock opname telah menyimpan data hasil penginputan maka aplikasi akan menampilkan laporan data stock opname yang merupakan tahap akhir dalam proses kegiatan stock opname.
\end{abstract}

Kata kunci: Stock Opname, BRM Group, Single Board Computer, Aplikasi, Portable 


\section{PENDAHULUAN}

Pemanfaatan teknologi mikrokontroler (komponen Single Board Computer) saat ini tidak terbatas sebagai fungsi pengendali di dalam industri saja tetapi sudah berkembang menjadi penggerak teknologi untuk kebutuhan sehari-hari baik dalam penelitian, kebutuhan rumah tangga maupun dalam bidang pendidikan.

Salah satu persoalan yang dihadapi oleh industri retail adalah persoalan memperbaharui (update) sistem rekam data stock opname. Sistem rekam data stock opname di BRM Group saat ini masih menggunakan sistem konvensional dengan menggunakan Form Input Stock Opname (FISO) untuk menginput data barang. Masalah yang timbul pada sistem rekam data stock opname konvensional adalah form mudah rusak, kesalahan penulisan data, pembuatan laporan stock opname yang tidak sesuai antara data fisik dan data sistem barang, yang berpotensi merugikan perusahaan. Perlu dibangun alat rekam data stock opname yang dapat meningkatkan efektifitas dan efisiensi kegiatan di BRM Group (seluruh cabang).

\section{PERANCANGAN PENELITIAN}

\subsection{Analisis Sistem yang Berjalan}

Saat ini sistem pelaksanaan stock opname yang berjalan di BRM Group masih menggunakan kertas sebagai alat utamanya, berikut tahapan yang dilakukan pada proses stock opname :

1. Kepala Toko menentukan area barang yang akan di stock.

2. Kepala Toko mencetak Form Input Stock Opname (FISO) yang telah ditentukan sesuai dengan kategori produk dan menyerahkan form tersebut kepada pramuniaga.

3. Melakukan penghitungan fisik stok barang pada suatu lokasi rak tertentu oleh petugas stock opname sesuai dengan FISO yang diberikan dari kepala toko.

4. Input hasil stock opname ke dalam format excel oleh petugas Inventory Control dan memberikan keterangan produk karena hasil input masih berupa barcode dan jumlah barang.

5. Petugas Inventory Control mengolah data hasil input agar barcode barang yang telah diinput pada FISO dapat melihat deskripsi barang tersebut.

6. Petugas Inventory Control membuat laporan data stock opname yang telah diinput secara detail. 
PETIR: Jurnal Pengkajian dan Penerapan Teknik Informatika

Vol. 13, No. 2, September 2020, P-ISSN 1978-9262, E-ISSN 2655-5018

DOI: https://doi.org/10.33322/petir.v13i2.1109

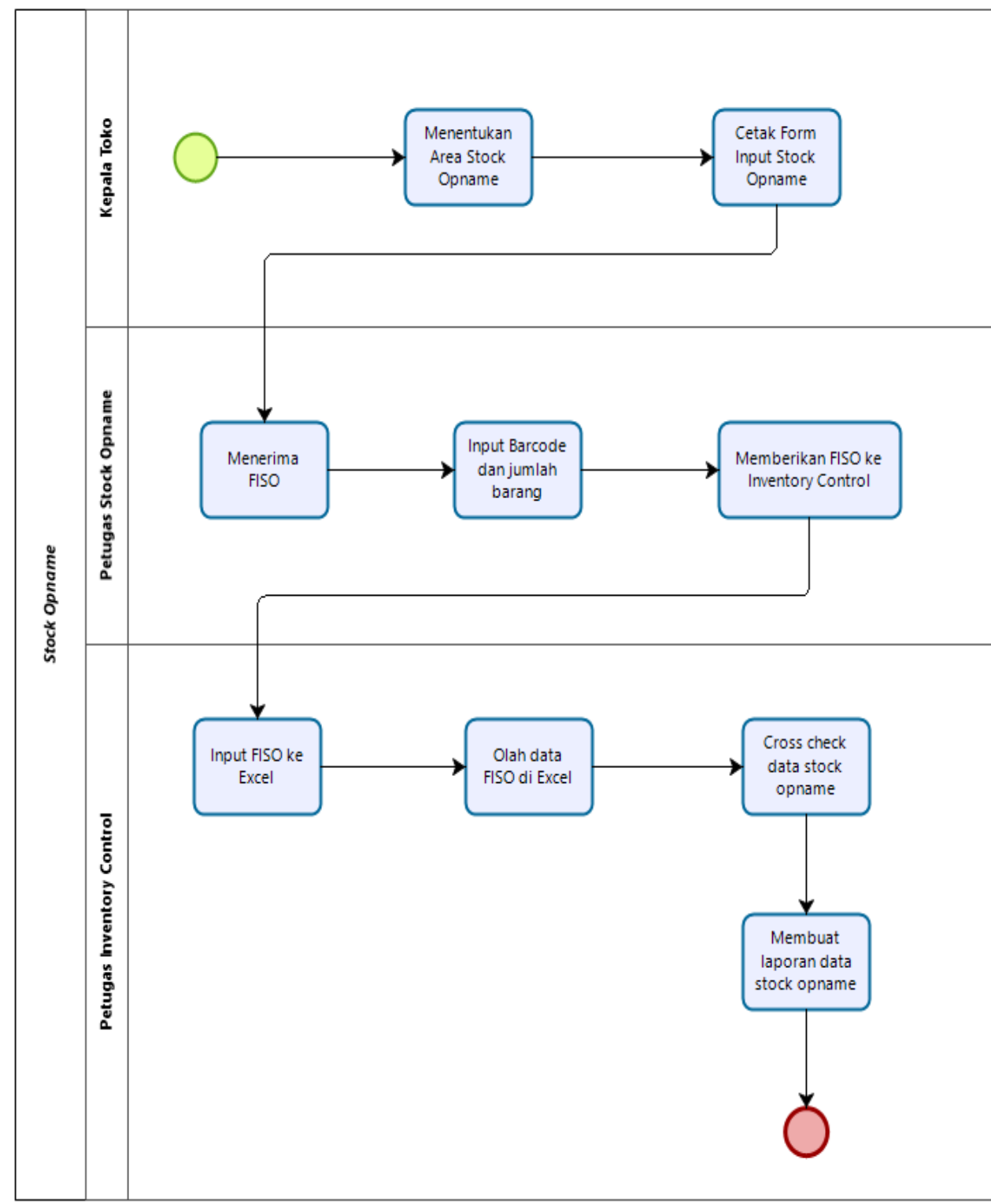

Gambar 1. Flowmap Sistem yang berjalan

\subsection{Analisis Sistem yang akan Dirancang}

Dari hasil analisis sistem yang sedang berjalan, maka sebagai solusinya dibangun sistem lebih sederhana yang akan dikembangkan, Alur sistem terlihat pada flow map di bawah ini. 


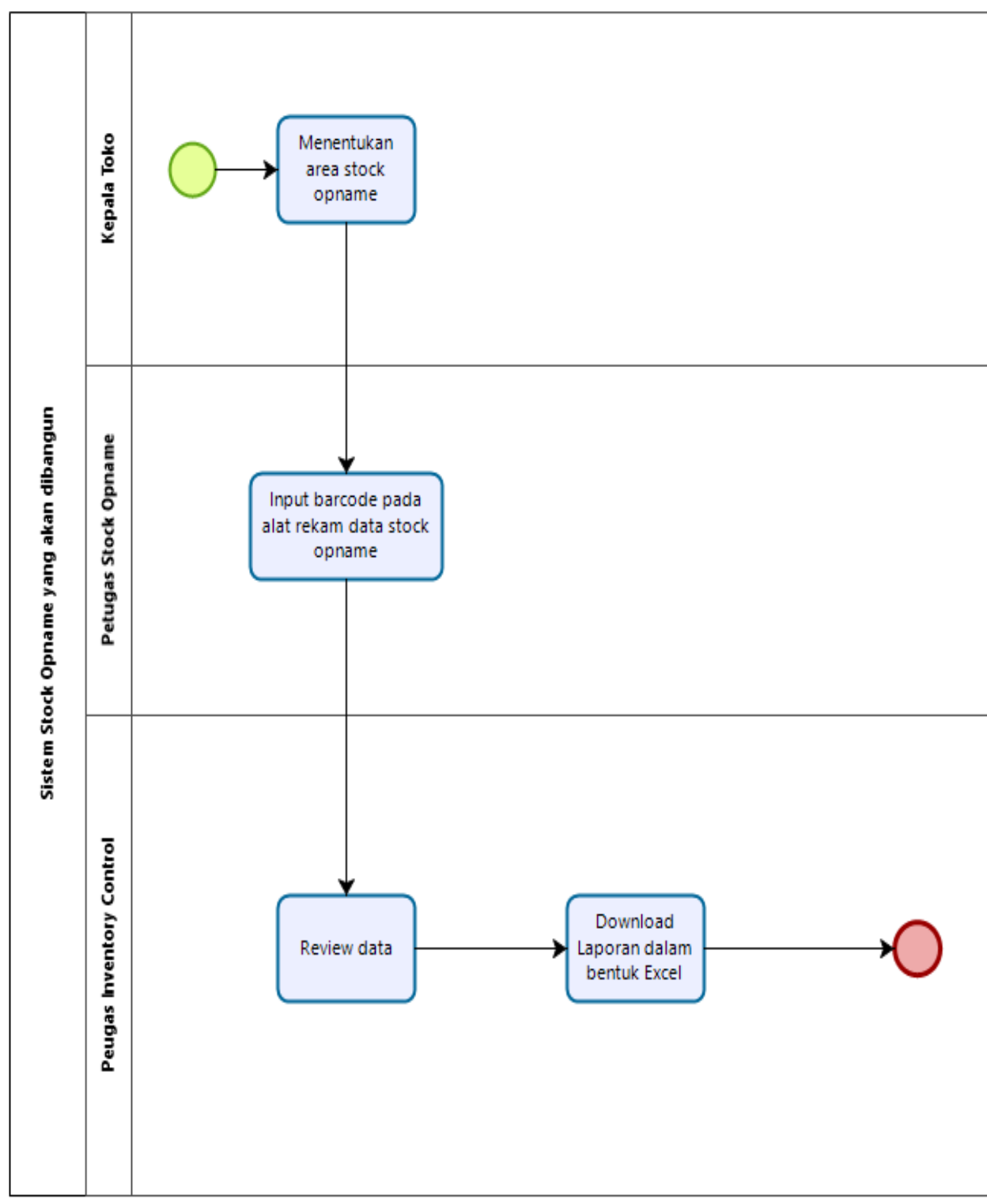

Gambar 2. Flow map sistem yang akan dibangun

\subsection{Blok Diagram}

Blok diagram adalah diagram dari sebuah sistem, dimana bagian utama atau fungsi yang telah diwakili oleh blok dihubungkan dengan garis, dengan memahami gambar blok diagram maka sistem yang akan dirancang sudah dapat dikenal dengan baik. Adapun gambaran dari blok diagram sistem yang akan dirancang adalah sebagai berikut: 


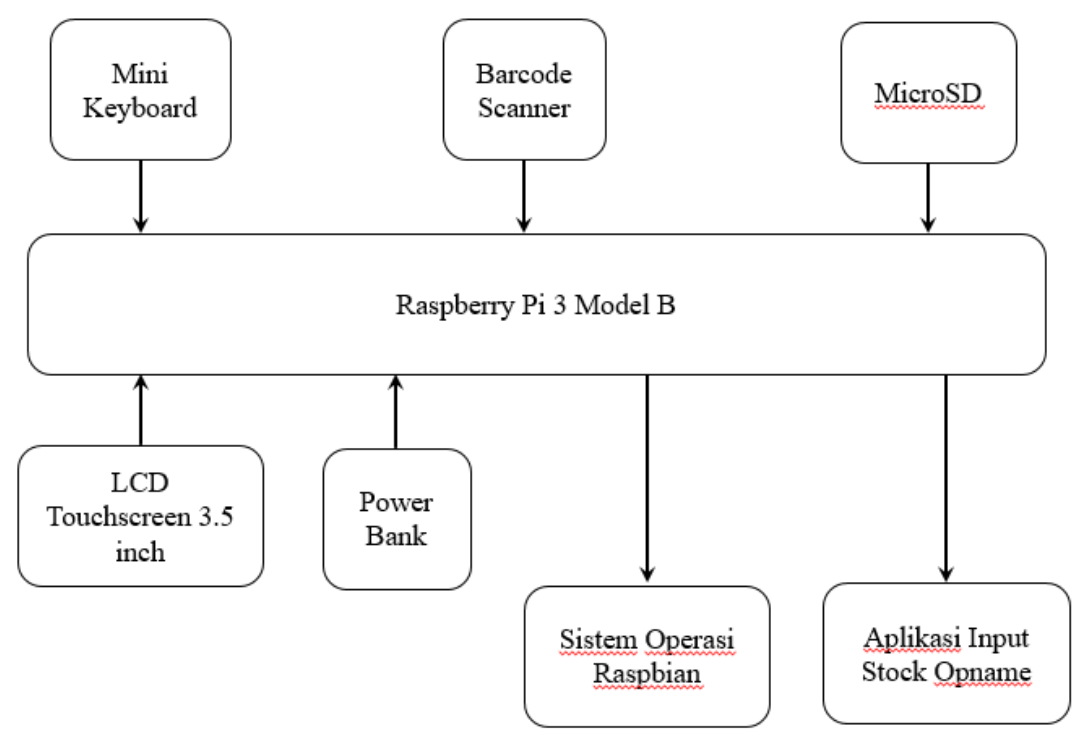

Gambar 3. Blok diagram alat rekam data stock opname

Barcode scanner mendeteksi barcode yang tertera pada setiap item barang, maka secara otomatis Raspberry Pi (Single Board Computer) akan memproses dan melakukan penyimpanan data melalui aplikasi rekam data stock opname.

\subsection{Perancangan Aplikasi Sistem}

Tahapan ini sangat penting, karena akan menentukan sistem baru sebagai solusi pemecahan masalah pada yang sistem lama. Pendekatan yang digunakan Object Oriented. Metode yang digunakan untuk menggambarkan seluruh proses yaitu Unified Modeling language (UML).

\subsubsection{Use Case Diagram}

Perancangan stock opname barang digambarkan oleh use case diagram berikut ini.

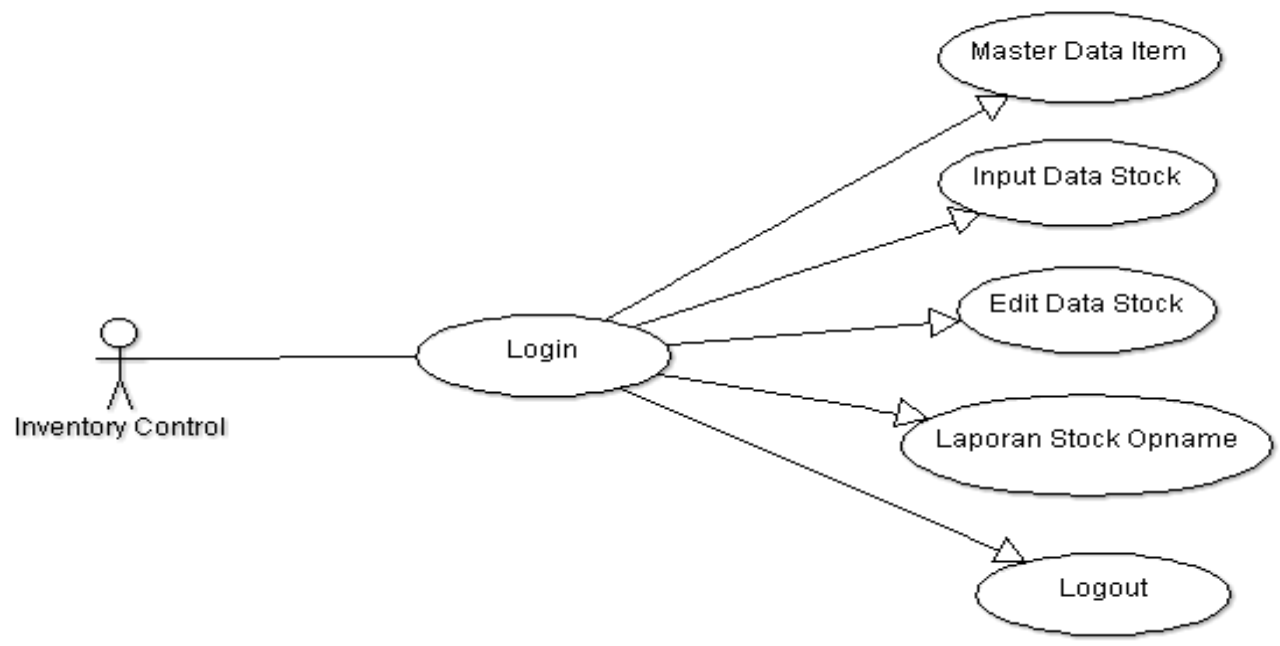

Gambar 4. UseCcase Diagram proses stock opname. 
PETIR: Jurnal Pengkajian dan Penerapan Teknik Informatika

Vol. 13, No. 2, September 2020, P-ISSN 1978-9262, E-ISSN 2655-5018 DOI: https://doi.org/10.33322/petir.v13i2.1109

\subsubsection{Activity Diagram}

Menggambarkan fungsi suatu sistem dan memberi tekanan pada aliran kendali antar objek.

\section{Activity Diagram akses Inventory Control}

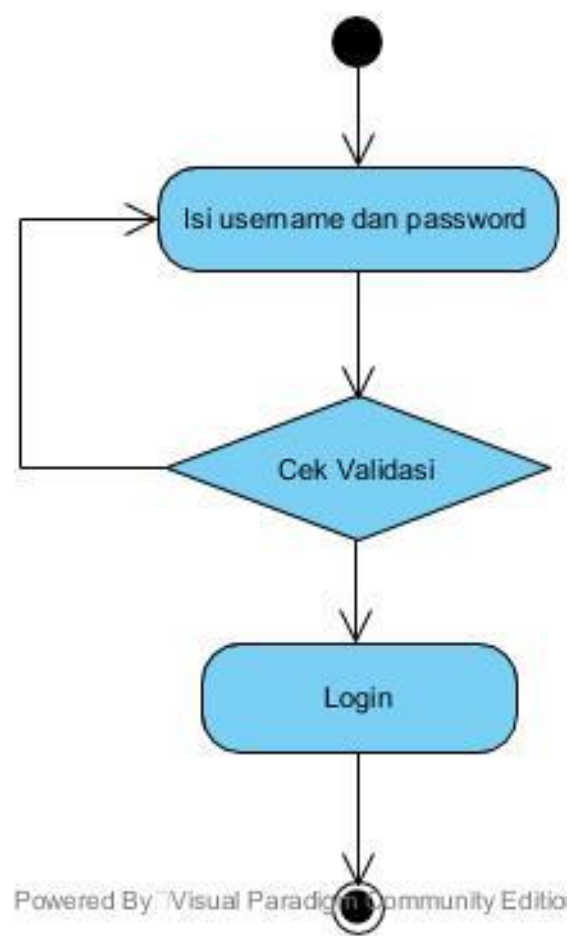

Gambar 5. Diagram activity akses inventory control

\section{Activity Diagram Master Item}

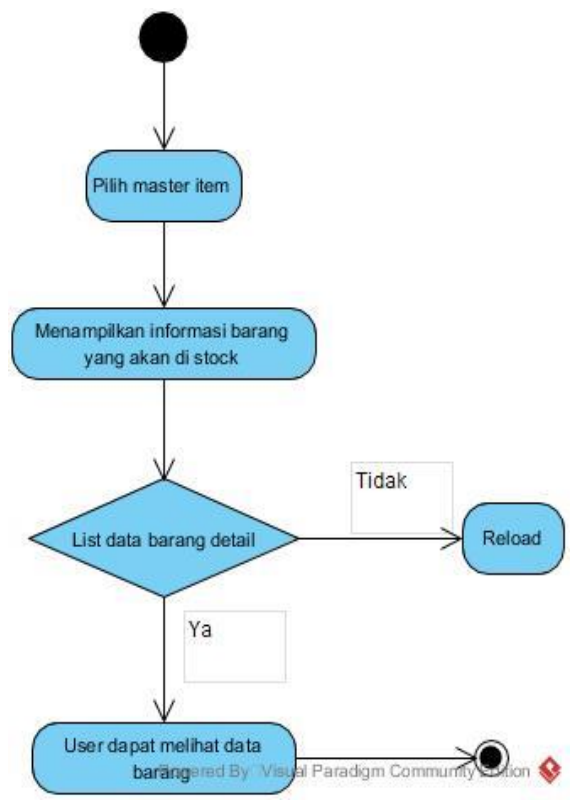

Gambar 6. Activity Diagram Master Item 
PETIR: Jurnal Pengkajian dan Penerapan Teknik Informatika

Vol. 13, No. 2, September 2020, P-ISSN 1978-9262, E-ISSN 2655-5018

DOI: https://doi.org/10.33322/petir.v13i2.1109

\section{Activity Diagram Input Stock Opname}

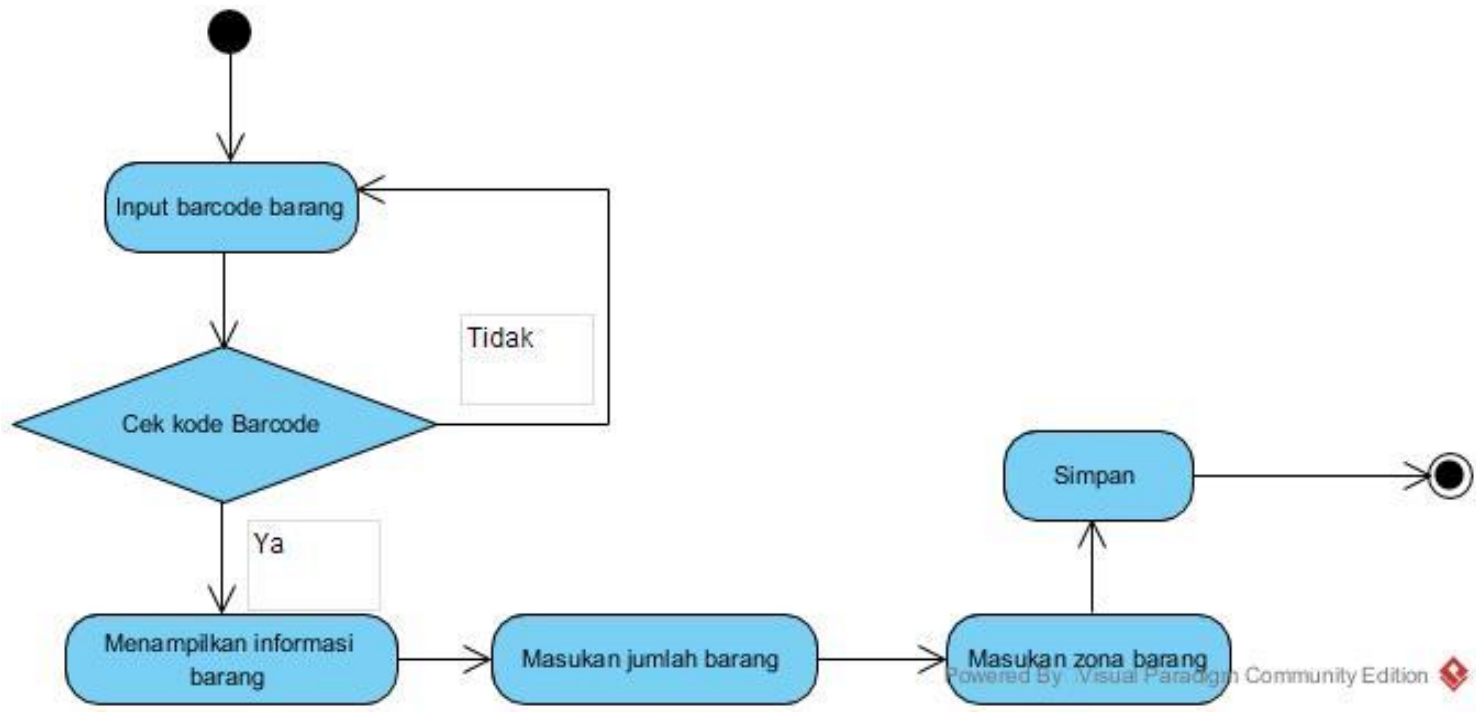

Gambar 7. Activity DiagramIinput Stock Opname

\section{Activity Diagram data stock opname}

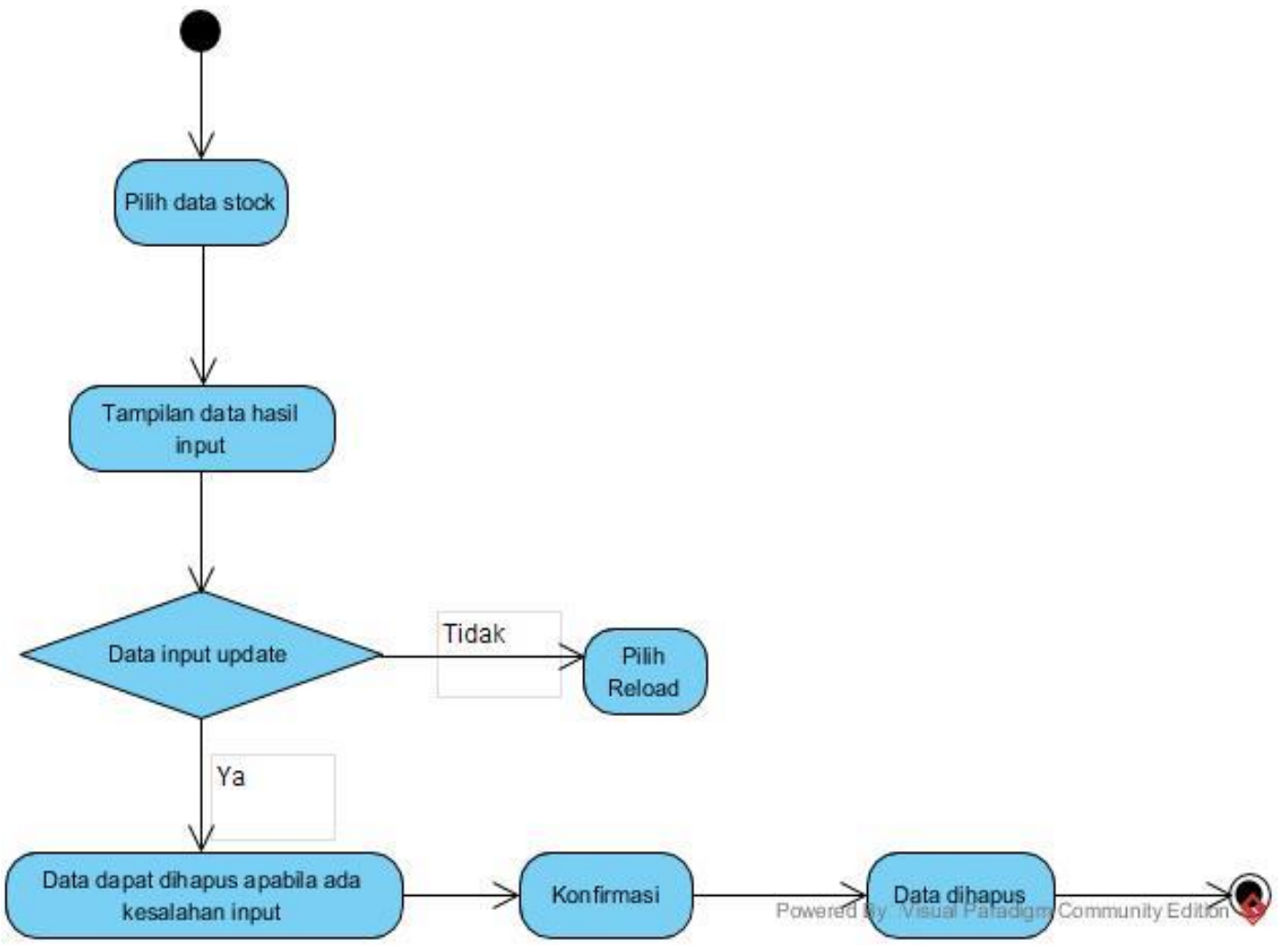

Gambar 8. Activity Diagram Data Stock Opname 
PETIR: Jurnal Pengkajian dan Penerapan Teknik Informatika

Vol. 13, No. 2, September 2020, P-ISSN 1978-9262, E-ISSN 2655-5018 DOI: https://doi.org/10.33322/petir.v13i2.1109

\section{Activity Diagram laporan stock opname}

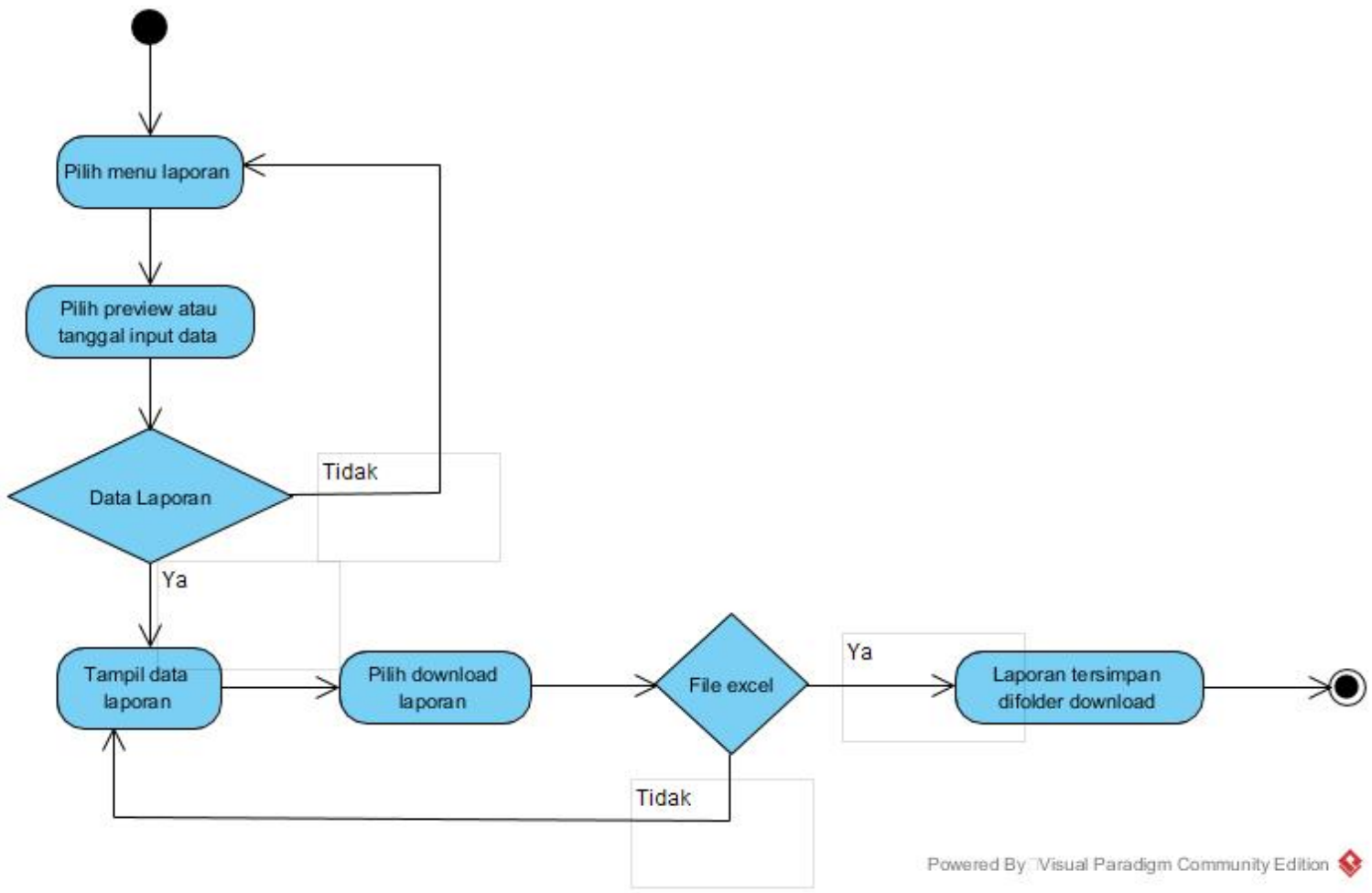

Gambar 9. Activity Diagram laporan stock opname

\subsubsection{Struktur Tabel}

Berikut ini beberapa table yang dibutuhkan untuk membuat aplikasi :

Tabel login

Nama tabel : user

Primary key : nama_user

Tabel 1. Login

\begin{tabular}{|c|c|c|c|}
\hline Nama Field & Type Data & Size & Deskripsi \\
\hline Nama_user & Varchar & 20 & Nama User \\
\hline Pw_user & Varchar & 50 & Password User \\
\hline
\end{tabular}

Tabel master item (Data Barang)

Nama tabel

: master_item

Primary key :id 
PETIR: Jurnal Pengkajian dan Penerapan Teknik Informatika

Vol. 13, No. 2, September 2020, P-ISSN 1978-9262, E-ISSN 2655-5018

DOI: https://doi.org/10.33322/petir.v13i2.1109

Tabel 2. Master_Item

\begin{tabular}{|c|c|c|c|}
\hline Nama Field & Type Data & Size & Deskripsi \\
\hline Id & Int & 11 & Id item \\
\hline Code & Varchar & 255 & SKU Barang \\
\hline Upc1 & Varchar & 255 & Barcode 1 \\
\hline Upc2 & Varchar & 255 & Barcode 2 \\
\hline Divisi & Varchar & 255 & Kategori Barang \\
\hline Dept & Varchar & 255 & Kategori Barang \\
\hline SubDept & Varchar & 255 & Kategori Barang \\
\hline Category & Varchar & 255 & Kategori Barang \\
\hline SupplierCode & Varchar & 255 & Kode Supplier \\
\hline SupplierName & Varchar & 255 & Nama Supplier \\
\hline Description & Varchar & 255 & Deskripsi Barang \\
\hline NStock & Double & - & Stock Barang \\
\hline Lastbuyprice & Double & - & Harga Beli \\
\hline CUnitHarga & Varchar & 255 & Harga unit satuan \\
\hline Lastbuydisscount & Varchar & 255 & Harga Beli Setelah \\
& & & Diskon \\
\hline Lastbuynetprice & Double & - & $\begin{array}{c}\text { Harga Beli Net } \\
\text { Setelah Diskon }\end{array}$ \\
\hline Currentsellprice & Double & - & Harga Jual \\
\hline Stockvalue & Double & - & Nilai Stock \\
\hline Pkitem & Varchar & 255 & Kode barang \\
\hline
\end{tabular}

Tabel laporan stock opname

Nama tabel

: data_so

Primary key

: no

Tabel 3. Laporan stock opname

\begin{tabular}{|l|l|l|l|}
\hline \multicolumn{1}{|c|}{ Nama Field } & \multicolumn{1}{|c|}{ Type Data } & \multicolumn{1}{c|}{ Size } & \multicolumn{1}{c|}{ Deskripsi } \\
\hline No & Int & 11 & Jumlah Rekam Data \\
\hline Date_time & Timestamp & - & Tanggal Input \\
\hline Code & Varchar & 40 & SKU Barang \\
\hline Upc1 & Varchar & 40 & Barcode 1 \\
\hline Upc2 & Varchar & 40 & Barcode 2 \\
\hline Stock & Int & 11 & Jumlah Stock Barang \\
\hline Zona & Varchar & 40 & Lokasi Barang \\
\hline Keterangan & Varchar & 100 & Keterangan Barang \\
\hline
\end{tabular}




\subsection{Diagram aplikasi alat rekam data stock opname berbasis Single Board Computer}

Berikut diagram aplikasi alat rekam data stock opname berbasis Single Board Computer.

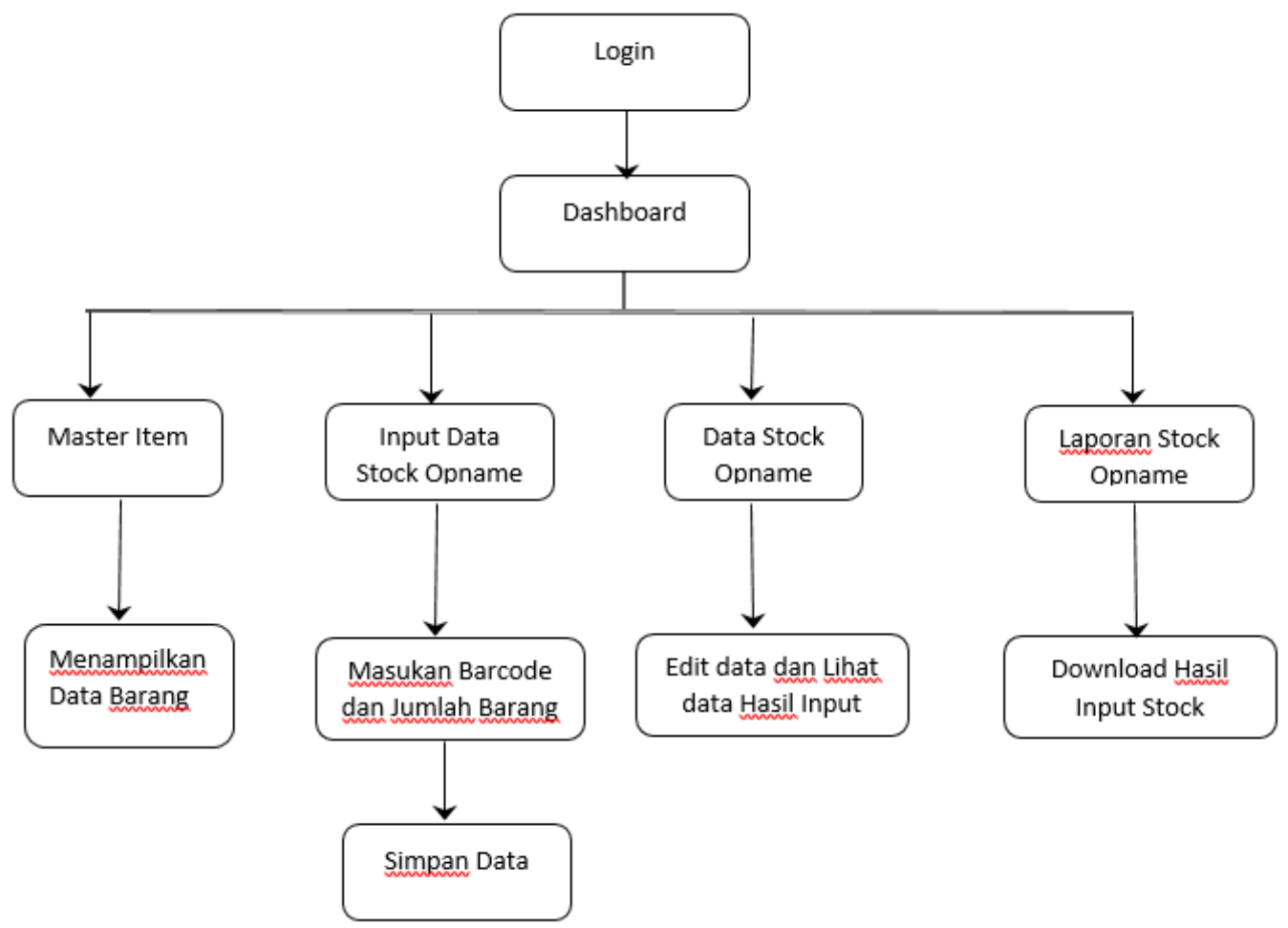

Gambar 10. Diagram aplikasi alat rekam data stock opname berbasis Single Board Computer

Aplikasi rekam data stock opname ini menjelaskan proses yang dimulai dari data barang yang dilakukan oleh bagian Inventory Control, kemudian bagian petugas stock opname dan gudang melakukan input data jumlah barang yang berada di area supermarket dan gudang. Setelah melakukan input jumlah data barang, bagian Inventory Control mencetak laporan hasil stock opname dan melakukan cross check antara hasil laporan stock opname dan jumlah barang yang telah di-input di area supermarket dan gudang.

\section{HASIL DAN PEMBAHASAN}

\subsection{Pengujian Aplikasi Rekam Data Stock Opname}

Pengujian aplikasi menggunakan Blackbox Testing. Hasil pengujian bisa dilihat pada tabel di bawah ini.

Tabel 4. Pengujian Blackbox Testing Aplikasi

\begin{tabular}{|c|l|l|l|l|}
\hline No & $\begin{array}{l}\text { Fungsi yang } \\
\text { diuji }\end{array}$ & Cara pengujian & Halaman yang diharapkan & Hasil pengujian \\
\hline 1 & Login & $\begin{array}{l}\text { Petugas stock } \\
\text { opname } \\
\text { memasukan } \\
\text { username dan } \\
\text { password }\end{array}$ & $\begin{array}{l}\text { Petugas stock opname masuk } \\
\text { ke halaman utama stock } \\
\text { opname }\end{array}$ & {$[$ ] ] Berhasil } \\
{$[$ [ ] Tidak Berhasil }
\end{tabular}


PETIR: Jurnal Pengkajian dan Penerapan Teknik Informatika

Vol. 13, No. 2, September 2020, P-ISSN 1978-9262, E-ISSN 2655-5018

DOI: https://doi.org/10.33322/petir.v13i2.1109

\begin{tabular}{|c|c|c|c|c|}
\hline 2 & $\begin{array}{l}\text { Menu master } \\
\text { item }\end{array}$ & $\begin{array}{l}\text { Klik menu } \\
\text { Master item }\end{array}$ & $\begin{array}{l}\text { Petugas stock opname dapat } \\
\text { melihat data barang secara } \\
\text { detail }\end{array}$ & $\begin{array}{l}{[\sqrt{ }] \text { Berhasil }} \\
{[\text { ] Tidak Berhasil }}\end{array}$ \\
\hline 3 & $\begin{array}{l}\text { Pencarian } \\
\text { master item }\end{array}$ & $\begin{array}{l}\text { Ketik deskripsi } \\
\text { data barang yang } \\
\text { akan dicari }\end{array}$ & $\begin{array}{l}\text { Petugas stock opname dapat } \\
\text { melihat barang yang dicari }\end{array}$ & $\begin{array}{l}{[\sqrt{ }] \text { Berhasil }} \\
{[\text { ] Tidak Berhasil }}\end{array}$ \\
\hline 4 & $\begin{array}{l}\text { Tampilan } \\
\text { baris }\end{array}$ & $\begin{array}{l}\text { Pilih tampilan } \\
\text { data barang } \\
\text { berdasarkan } \\
\text { berapa banyak } \\
\text { baris yang akan } \\
\text { ditampilkan }\end{array}$ & $\begin{array}{l}\text { Petugas stock opname dapat } \\
\text { melihat data barang sesuai } \\
\text { dengan baris yang telah dipilih }\end{array}$ & $\begin{array}{l}{[\sqrt{ }] \text { Berhasil }} \\
\text { [ ] Tidak Berhasil }\end{array}$ \\
\hline 5 & Reload & Klik reload & $\begin{array}{l}\text { Petugas stock opname dapat } \\
\text { merefresh kembali data barang }\end{array}$ & $\begin{array}{l}{[\sqrt{ }] \text { Berhasil }} \\
\text { [ ] Tidak Berhasil }\end{array}$ \\
\hline 6 & $\begin{array}{l}\text { Tampilan } \\
\text { page }\end{array}$ & $\begin{array}{l}\text { Klik page yang } \\
\text { akan ditampilkan }\end{array}$ & $\begin{array}{l}\text { Petugas stock opname dapat } \\
\text { melihat data barang sesuai } \\
\text { page yang di pilih }\end{array}$ & $\begin{array}{l}{[\sqrt{ }] \text { Berhasil }} \\
\text { [ ] Tidak Berhasil }\end{array}$ \\
\hline 7 & $\begin{array}{l}\text { Tombol } \\
\text { kembali }\end{array}$ & $\begin{array}{l}\text { Klik tombol } \\
\text { kembali }\end{array}$ & $\begin{array}{l}\text { Petugas stock opname dapat } \\
\text { kembali ke halaman dashboard }\end{array}$ & $\begin{array}{l}{[\sqrt{ }] \text { Berhasil }} \\
{[\text { ] Tidak Berhasil }}\end{array}$ \\
\hline 8 & Tombol logout & $\begin{array}{l}\text { Klik tombol } \\
\text { logout }\end{array}$ & $\begin{array}{l}\text { Petugas stock opname akan } \\
\text { keluar dari menu }\end{array}$ & $\begin{array}{l}{[\sqrt{ }] \text { Berhasil }} \\
{[\text { ] Tidak Berhasil }}\end{array}$ \\
\hline 9 & $\begin{array}{l}\text { Menu input } \\
\text { stock opname }\end{array}$ & $\begin{array}{l}\text { Klik menu input } \\
\text { stock opname }\end{array}$ & $\begin{array}{l}\text { Petugas stock opname akan } \\
\text { masuk ke menu input stock } \\
\text { opname }\end{array}$ & $\begin{array}{l}{[\sqrt{ }] \text { Berhasil }} \\
{[\text { ] Tidak Berhasil }}\end{array}$ \\
\hline 10 & Kolom item & $\begin{array}{l}\text { Scan barcode } \\
\text { barang pada } \\
\text { kolom item }\end{array}$ & $\begin{array}{l}\text { Petugas stock opname dapat } \\
\text { melihat detail data barang dan } \\
\text { kolom code, upc1, upc } 2 \text { dan } \\
\text { deskripsi barang akan otomatis } \\
\text { terisi }\end{array}$ & $\begin{array}{l}{[\sqrt{ }] \text { Berhasil }} \\
\text { [ ] Tidak Berhasil }\end{array}$ \\
\hline 11 & Kolom zona & $\begin{array}{l}\text { Ketik zona input } \\
\text { barang }\end{array}$ & $\begin{array}{l}\text { Petugas stock opname dapat } \\
\text { mengetahui posisi barang } \\
\text { berdasarkan zona yang telah } \\
\text { diinput }\end{array}$ & $\begin{array}{l}{[\sqrt{ }] \text { Berhasil }} \\
\text { [ ] Tidak Berhasil }\end{array}$ \\
\hline 12 & $\begin{array}{l}\text { Kolom } \\
\text { keterangan }\end{array}$ & $\begin{array}{l}\text { Ketik keterangan } \\
\text { barang pada saat } \\
\text { input barang }\end{array}$ & $\begin{array}{l}\text { Petugas stock opname dapat } \\
\text { mengetahui keterangan barang } \\
\text { berdasarkan keterangan yang } \\
\text { telah diinput }\end{array}$ & $\begin{array}{l}{[\sqrt{ }] \text { Berhasil }} \\
\text { [ ] Tidak Berhasil }\end{array}$ \\
\hline 13 & $\begin{array}{l}\text { Tombol } \\
\text { simpan }\end{array}$ & $\begin{array}{l}\text { Klik tombol } \\
\text { simpan }\end{array}$ & $\begin{array}{l}\text { Petugas stock opname dapat } \\
\text { menyimpan data barang yang } \\
\text { telah diinput }\end{array}$ & $\begin{array}{l}{[\sqrt{ }] \text { Berhasil }} \\
{[\text { ] Tidak Berhasil }}\end{array}$ \\
\hline
\end{tabular}


PETIR: Jurnal Pengkajian dan Penerapan Teknik Informatika

Vol. 13, No. 2, September 2020, P-ISSN 1978-9262, E-ISSN 2655-5018

DOI: https://doi.org/10.33322/petir.v13i2.1109

\begin{tabular}{|c|c|c|c|c|}
\hline 14 & Tombol back & Klik tombol back & $\begin{array}{l}\text { Petugas stock opname akan } \\
\text { masuk ke halaman utama }\end{array}$ & $\begin{array}{l}{[\sqrt{ }] \text { Berhasil }} \\
{[\text { ] Tidak Berhasil }}\end{array}$ \\
\hline 15 & $\begin{array}{l}\text { Tombol } \\
\text { Logout }\end{array}$ & $\begin{array}{l}\text { Klik tombol } \\
\text { logout }\end{array}$ & $\begin{array}{l}\text { Petugas stock opname akan } \\
\text { kembali ke halaman login }\end{array}$ & $\begin{array}{l}{[\sqrt{ }] \text { Berhasil }} \\
{[\text { ] Tidak Berhasil }}\end{array}$ \\
\hline 16 & $\begin{array}{l}\text { Menu data } \\
\text { stock opname }\end{array}$ & $\begin{array}{l}\text { Klik menu data } \\
\text { stock opname }\end{array}$ & $\begin{array}{l}\text { Petugas stock opname akan } \\
\text { masuk ke dalam menu data } \\
\text { stock opname dan dapat } \\
\text { melihat data hasil input stock } \\
\text { opname }\end{array}$ & $\begin{array}{l}{[\sqrt{ }] \text { Berhasil }} \\
{[\text { ] Tidak Berhasil }}\end{array}$ \\
\hline 17 & $\begin{array}{l}\text { Kolom } \\
\text { Pencarian }\end{array}$ & $\begin{array}{l}\text { Ketik pencarian } \\
\text { barang pada } \\
\text { kolom pencarian }\end{array}$ & $\begin{array}{l}\text { Petugas dapat menemukan data } \\
\text { stock yang telah diinput sesuai } \\
\text { dengan pencarian yang telah } \\
\text { ditentukan }\end{array}$ & $\begin{array}{l}{[\sqrt{ }] \text { Berhasil }} \\
\text { [ ] Tidak Berhasil }\end{array}$ \\
\hline 18 & $\begin{array}{l}\text { Tampilan } \\
\text { baris }\end{array}$ & $\begin{array}{l}\text { Pilih tampilan } \\
\text { baris yang akan } \\
\text { ditentukan }\end{array}$ & $\begin{array}{l}\text { Petugas stock opname akan } \\
\text { melihat data sesuai baris yang } \\
\text { telah ditentukan }\end{array}$ & $\begin{array}{l}{[\sqrt{ }] \text { Berhasil }} \\
\text { [ ] Tidak Berhasil }\end{array}$ \\
\hline 19 & Tombol hapus & $\begin{array}{l}\text { Klik tombol } \\
\text { hapus }\end{array}$ & $\begin{array}{l}\text { Petugas stock opname dapat } \\
\text { menghapus data input stock } \\
\text { opname dikarenakan kesalahan } \\
\text { pada saat proses input data }\end{array}$ & $\begin{array}{l}{[\sqrt{ }] \text { Berhasil }} \\
\text { [ ] Tidak Berhasil }\end{array}$ \\
\hline 20 & $\begin{array}{l}\text { Tombol } \\
\text { kembali }\end{array}$ & $\begin{array}{l}\text { Klik tombol } \\
\text { kembali }\end{array}$ & $\begin{array}{l}\text { Petugas stock opname akan } \\
\text { kembali pada menu halaman } \\
\text { utama stock opname }\end{array}$ & $\begin{array}{l}{[\sqrt{ }] \text { Berhasil }} \\
{[\text { ] Tidak Berhasil }}\end{array}$ \\
\hline 21 & Tombol logout & $\begin{array}{l}\text { Klik tombol } \\
\text { logout }\end{array}$ & $\begin{array}{l}\text { Petugas stock opname akan } \\
\text { kembali ke halaman login }\end{array}$ & $\begin{array}{l}{[\sqrt{ }] \text { Berhasil }} \\
{[\text { ] Tidak Berhasil }}\end{array}$ \\
\hline 22 & $\begin{array}{l}\text { Tombol } \\
\text { reload }\end{array}$ & $\begin{array}{l}\text { Klik tombol } \\
\text { reload }\end{array}$ & $\begin{array}{l}\text { Petugas stock opname dapat } \\
\text { merefresh kembali data stock } \\
\text { opname yang telah }\end{array}$ & $\begin{array}{l}{[\sqrt{ }] \text { Berhasil }} \\
{[\text { ] Tidak Berhasil }}\end{array}$ \\
\hline 23 & $\begin{array}{l}\text { Menu laporan } \\
\text { data stock } \\
\text { opname } \\
\end{array}$ & $\begin{array}{l}\text { Klik tombol } \\
\text { menu laporan } \\
\text { stock opname }\end{array}$ & $\begin{array}{l}\text { Petugas stock opname dapat } \\
\text { melihat menu laporan stock } \\
\text { opname }\end{array}$ & $\begin{array}{l}{[\sqrt{ }] \text { Berhasil }} \\
\text { [ ] Tidak Berhasil }\end{array}$ \\
\hline 24 & $\begin{array}{l}\text { Tombol } \\
\text { Preview data } \\
\text { laporan stock } \\
\text { opname }\end{array}$ & $\begin{array}{l}\text { Masukan tanggal } \\
\text { input data stock } \\
\text { dan klik preview }\end{array}$ & $\begin{array}{l}\text { Petugas stock opname dapat } \\
\text { melihat data stock yang telah } \\
\text { diinput sesuai dengan tanggal } \\
\text { yang telah ditentukan }\end{array}$ & $\begin{array}{l}{[\sqrt{ }] \text { Berhasil }} \\
\text { [ ] Tidak Berhasil }\end{array}$ \\
\hline 25 & $\begin{array}{l}\text { Tombol } \\
\text { Export to } \\
\text { Excel }\end{array}$ & $\begin{array}{l}\text { Klik export to } \\
\text { excel }\end{array}$ & $\begin{array}{l}\text { Petugas stock opname dapat } \\
\text { mendownload hasil data stock } \\
\text { opname dalam bentuk file } \\
\text { excel }\end{array}$ & $\begin{array}{l}{[\sqrt{ }] \text { Berhasil }} \\
\text { [ ] Tidak Berhasil }\end{array}$ \\
\hline 26 & $\begin{array}{l}\text { Tombol } \\
\text { Logout }\end{array}$ & $\begin{array}{l}\text { Klik tombol } \\
\text { logout }\end{array}$ & $\begin{array}{l}\text { Petugas stock opname akan } \\
\text { kembali ke halaman login }\end{array}$ & $\begin{array}{l}{[\sqrt{ }] \text { Berhasil }} \\
\text { [ ] Tidak Berhasil }\end{array}$ \\
\hline
\end{tabular}


PETIR: Jurnal Pengkajian dan Penerapan Teknik Informatika

Vol. 13, No. 2, September 2020, P-ISSN 1978-9262, E-ISSN 2655-5018

DOI: https://doi.org/10.33322/petir.v13i2.1109

\subsection{Pengujian Alat Rekam Data Stock Opname}

Pada saat pengujian barang yang telah di-scan kode barcodenya akan menampilkan detail barang tersebut pada menu input stock opname lalu masukan jumlah stock, area dan keterangan barang tersebut lalu simpan data input. Hasil pengujian ketika barang telah berhasil di input di menu input stock opname dapat ditampilkan pada pada gambar berikut :

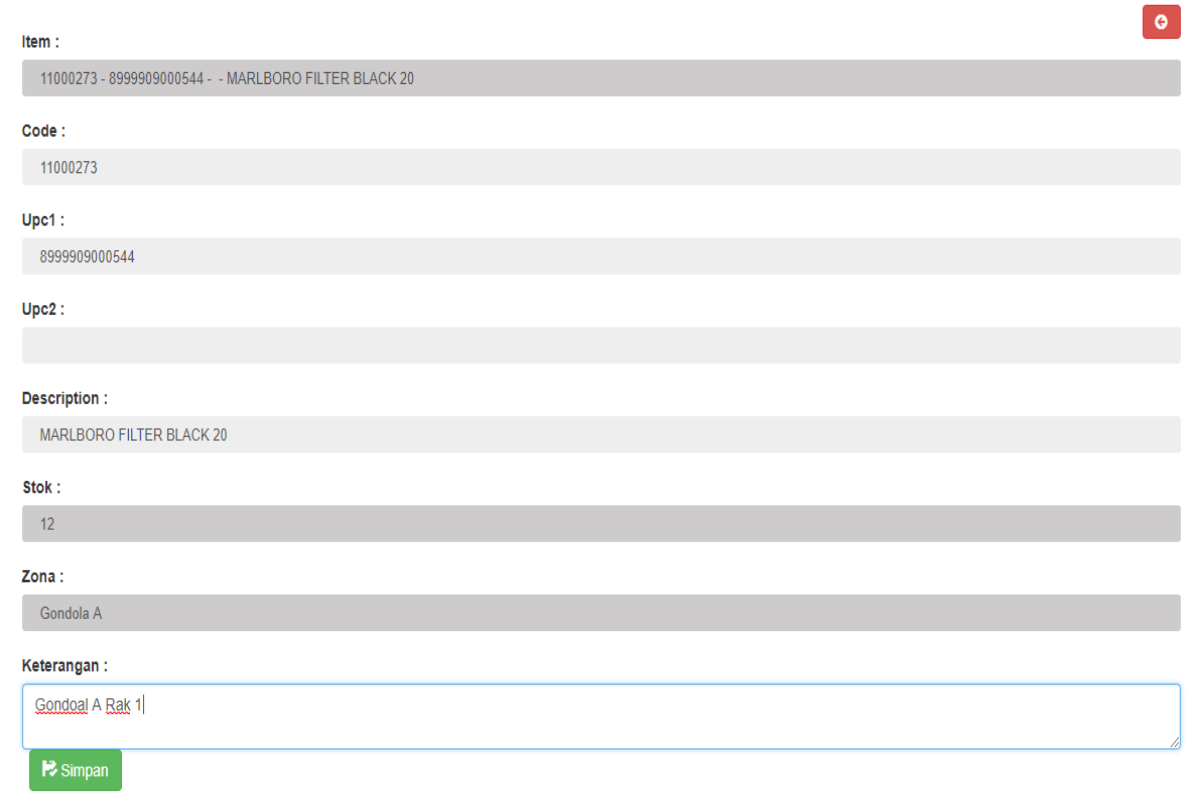

Gambar 11. Pengujian menu input stock opname

Pada saat pengujian barang yang telah diinput selanjutnya data akan tersimpan di menu data stock opname apabila ada kesalahan input pengguna dapat menghapus barang tersebut di menu data stock opname. Hasil pengujian ketika barang yang telah di-input tersimpan di menu data stock opname ditampilkan pada gambar berikut:

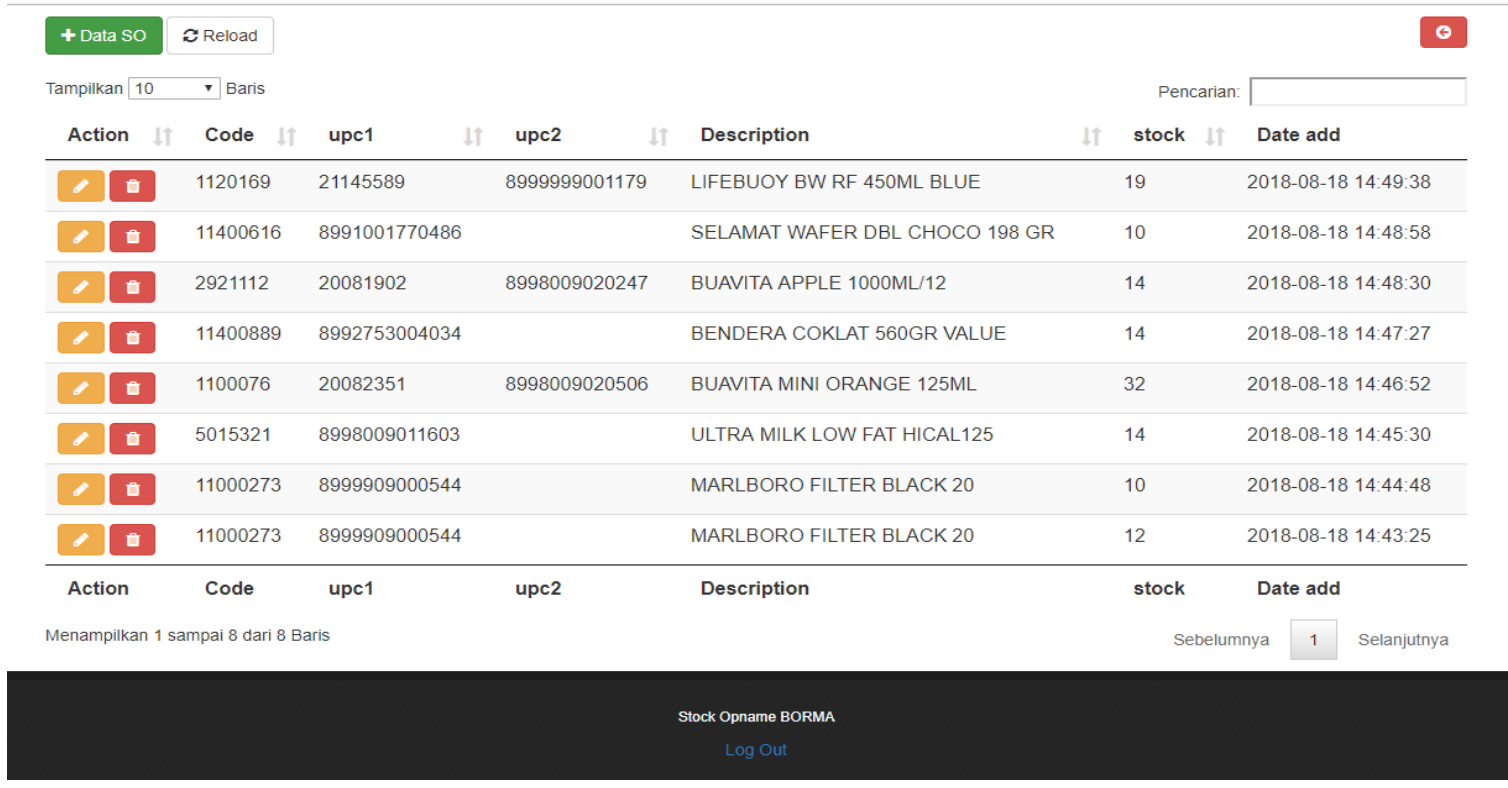

Gambar 12. Menu data stock opname 
Pada saat pengujian menu data laporan stock opname yang merupakan laporan data barang yang telah di input dalam menu laporan data stock opname petugas inventory control dapat melihat data barang yang di input pada saat stock opname berdasarkan tanggal input dan laporan dapat didownload dalam bentuk excel. Hasil pengujian menu laporan data stock opname ditampilkan pada gambar berikut :

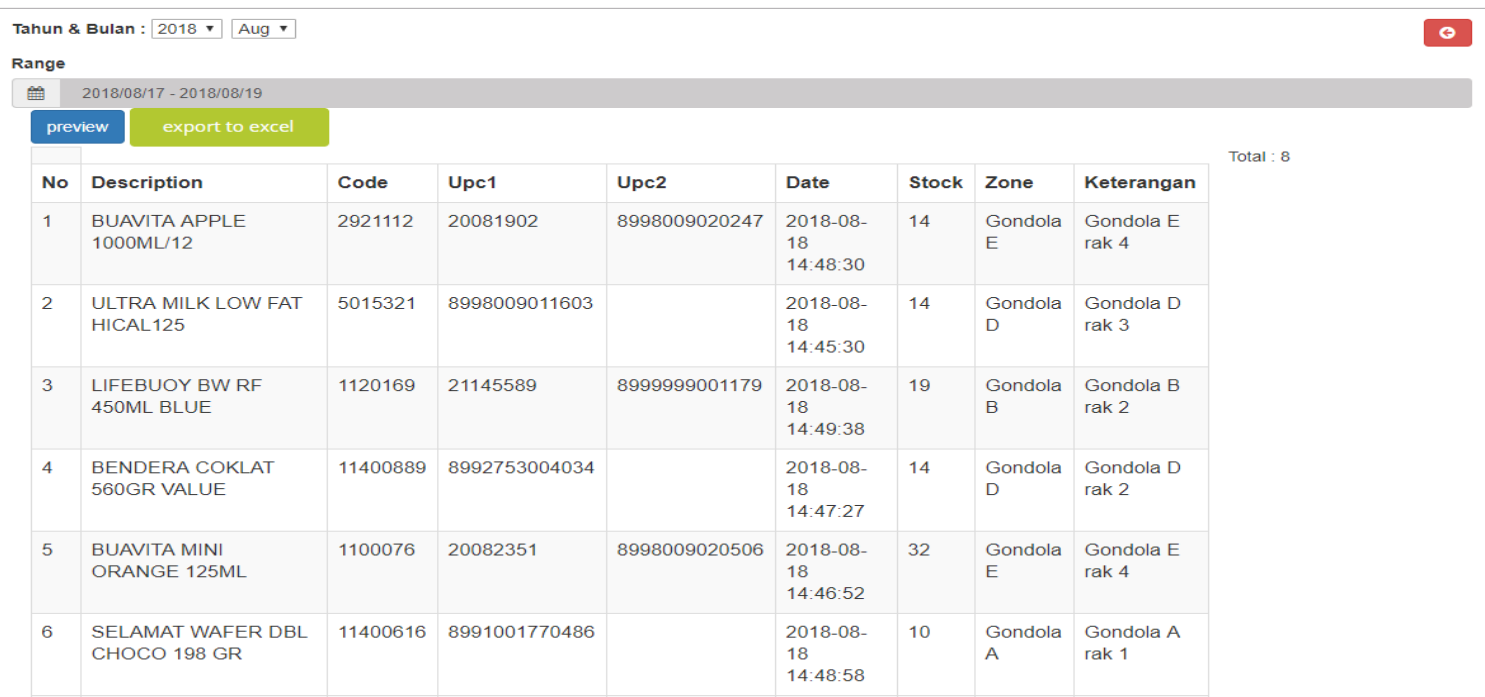

Gambar 13. Menu Laporan Stock Opname

Pada saat pengujian hasil download laporan dari menu data laporan stock opname yang merupakan bentuk laporan data stock opname untuk petugas inventory control. Hasil pengujian laporan data stock opname dalam bentuk excel ditampilkan pada gambar berikut :

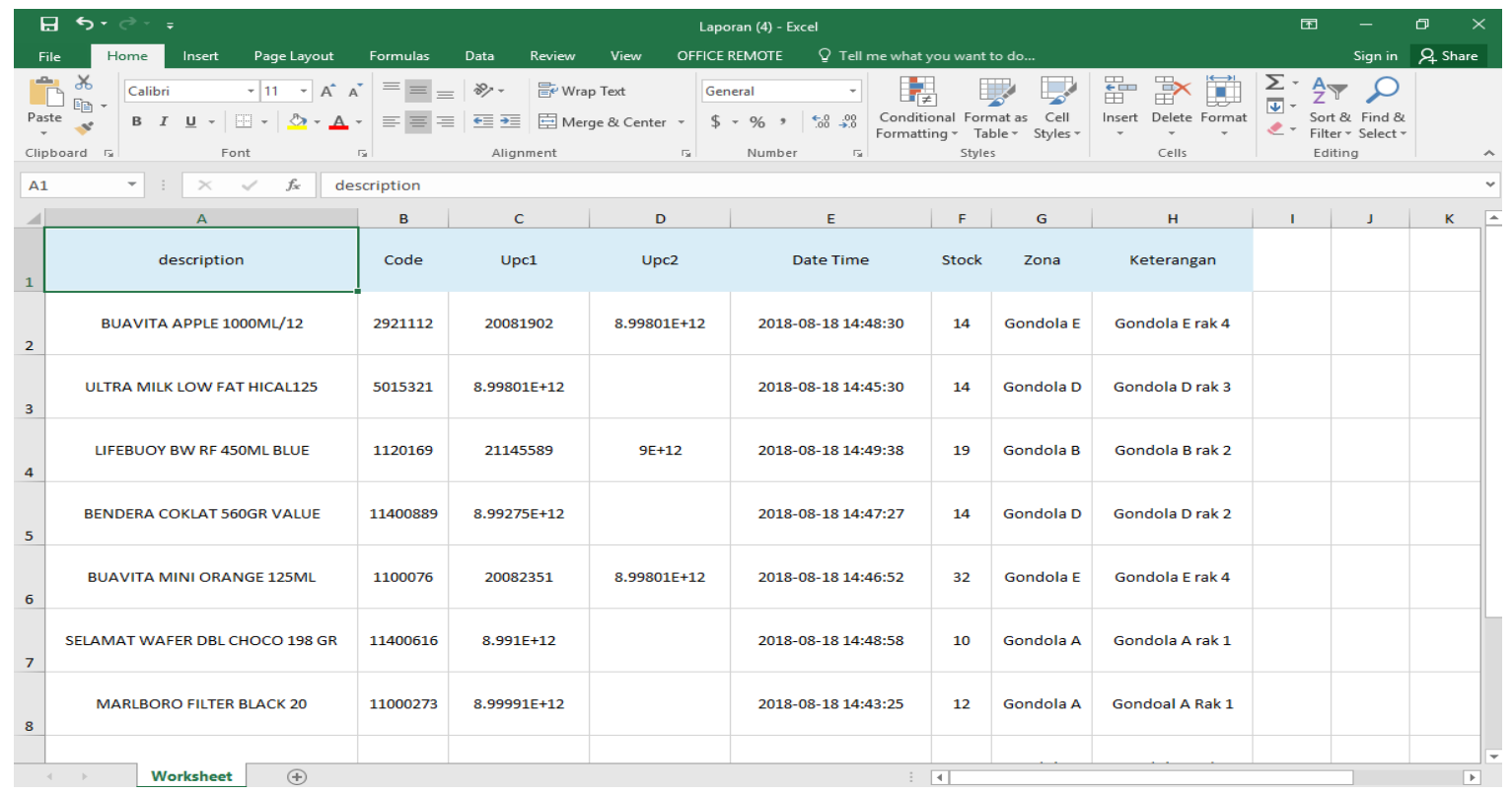

Gambar 14. Laporan stock opname dalam bentuk excel 
PETIR: Jurnal Pengkajian dan Penerapan Teknik Informatika

Vol. 13, No. 2, September 2020, P-ISSN 1978-9262, E-ISSN 2655-5018

DOI: https://doi.org/10.33322/petir.v13i2.1109

\section{KESIMPULAN DAN SARAN}

Semua device dan aplikasi rekam data stock opname yang terintegrasi pada raspberry pi 3 model B dapat terkoneksi dengan baik. Sehingga alat rekam data stock opname berbasis SBC ini dapat membantu proses digitalisasi data stock opname serta meningkatkan kinerja operasional, yaitu proses input data dan pembuatan laporan data stock opname lebih efektif dan efisien serta meningkatkan produktivitas petugas Inventory Control.

Hal yang perlu diperhatikan untuk pengembangan aplikasi ini adalah adanya tingkatan level pengguna (hak akses), baik sisi admin maupun petugas Inventory Control, guna membedakan hak akses dan pembagian tugas (job description).

Dinamika perusahaan akan terus berubah seiring dengan perkembangan kemajuan teknologi informasi, agar dapat bekerja dengan optimal maka kegiatan stock opname (aplikasi sistem) harus selalu mengikuti (allign) dengan prosedur perusahaan.

\section{DAFTAR PUSTAKA}

[1] Achour, M, Friedhelm. B, Anthony. D, Nuno. L, Hannes.M, George. R, Damien. S dan Jakub. V. 2007. PHP Manual. The Documentation Group.

[2] Edi Rakhman. 2014. Raspberry Pi Mikrokontroller Mungil yang Serba Bisa. Yogyakarta: ANDI Yogyakarta

[3] Fatansyah, B. 1999. Basis Data. Bandung: Informatika.

[4] Jamsa, K, Konrad.K dan Andy.A. 2002. HTML \& Web Design Tips \& Techniques. USA: McGraw-Hill Companies

[5] Liliana, Efisiensi Sistem Inventarisasi Pada Unit Perbekalan Universitas Kristen Petra Dengan Penerapan Sistem Stok Opname Menggunakan Barcode Reader, ISSN: 2089-1121, 1-8 (2011).

[6] Nugroho, Bunafit. 2014. Pemrograman Web: Membuat Sistem Informasi Akademik Sekolah dengan PHP-MySql dan Dreamweaver. Yogyakarta: Gava Media.

[7] Rahmadi, Lendy dan Kusnita Yusmiarti. Perancangan Sistem Informasi Inventory di Amik Lembah Dempo Pagaralam, Jurnal Sarjana Teknik Informatika, ISSN: 2302-3805. Vol 2, No.2, Juni 2014.

[8] http://raspberrypi.org/products/model-b/ (diakses pada Januari 2020)

[9] http://repository.uksw.edu/bitstream/123456789/11454/1/T1_672012161_Abstract.pdf

[10] Upton, Eben \& Gareth Halfacree. 2012. Raspberry Pi User Guide. United Kingdom: John Wiley \& Sons, Ltd., Publication. 